PHILIP BROWNSEY, Rangeland

Restoration Academic Coordinator, Sierra Foothill Research and Extension Center; JOSH DAVY, Livestock, Range, and Natural

Resources Advisor, Tehama, Colusa, and Glenn Counties; THERESA

BECCHETTI, Livestock and Natural Resources Farm Advisor, San Joaquin and Stanislaus Counties; MADDISON L. EASLEY, Staff Research Associate, Sierra Foothill Research and Extension Center; JEREMEY J. JAMES, Director, Sierra Foothill Research and Extension Center; and EMILIO A. LACA, Professor, Department of Plant Sciences, University of California, Davis

\section{Barb Goatgrass and Medusahead: Timing of Grazing and Mowing Treatments}

\author{
D) arb
} arb goatgrass (Aegillops triuncialis $\mathrm{L}_{\text {.) }}$ ) and medusahead (Taeniatherum caput-medusae ( $\mathrm{L}_{\text {. }}$ ) Nevski) are invasive annual grasses that have spread or have the potential to spread throughout much of California's annual grasslands. Originally from the Mediterranean, Middle Eastern, and Central Asian regions, these species were first introduced to the western United States in the late 1800 s or early 1900 s.

Barb goatgrass primarily occurs in California, although there are records from Washington, Oregon, and Nevada, as well as from some mid-Atlantic states (Meimberg et al. 2006). Medusahead is widespread in California and the Intermountain West, occupying roughly 2.4 million acres across the western United States (Duncan et al. 2004). Estimates for the extent of barb goatgrass infestation are not currently available, though it is much less widespread than medusahead. Barb goatgrass is a B-rated noxious weed and medusahead is a C-rated noxious weed in the State of California, meaning that they both cause economic or environmental detriment. Barb goatgrass has a higher rating due to its more limited distribution and, therefore, greater opportunity for containment than

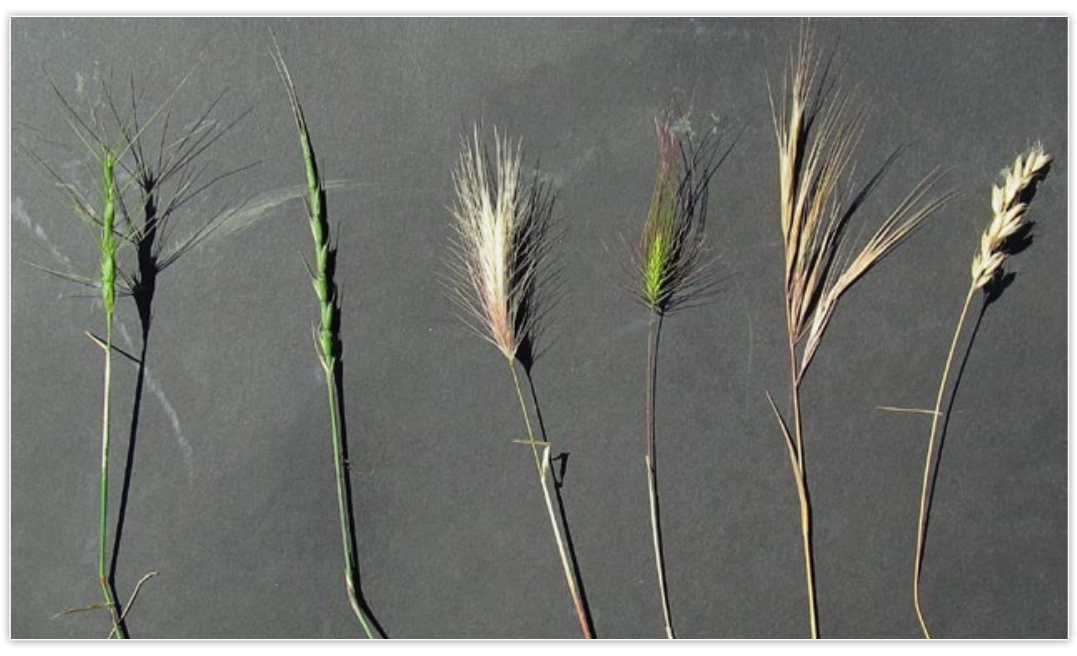

Figure 1. Barb goatgrass and medusahead compared with other common annual grasses, showing a later phenology. Left to right: Barb goatgrass, jointed goatgrass, hare barley, medusahead, ripgut brome, soft brome. Photo: J. Davy. 
medusahead. Both of these species commonly occur with other exotic annual grasses (fig. 1).

As annual grasses, barb goatgrass and medusahead produce seed at the end of the growing season (late spring) for subsequent germination in the fall. Inhibiting this seed production is crucial to suppressing or controlling both weeds. Grazing and mowing can be successful tools for accomplishing this task if used at the proper timing. Unfortunately, barb goatgrass and medusahead are prolific seed producers, making management to reduce their abundance possible but eradication difficult and unlikely. Barb goatgrass compounds this problem because in addition to producing seed for the following season, it also produces a dormant set of seed that will not germinate until the second growing season after seed production, making 2 years of control necessary to reduce infestations. For these reasons, grazing has not yet proven to be a fully successful strategy for depleting stands of barb goatgrass. Mowing prior to seed maturity may be a better mechanism to control barb goatgrass. Fortunately, medusahead populations can be drastically reduced with a single event that suppresses seed production, lending it to both grazing and mowing treatment methods. Both of these methods require appropriate timing so that the mechanism matches the biological susceptibility of the plant for successful management.

The timing of growth events, including major biological changes in plant growth and development through the season, is referred to as phenology. As applied to managing invasive annual grasses, the important events to consider include germination, vegetative growth phases, and a series of reproductive growth phases that end in the production of viable seed.

As barb goatgrass and medusahead develop and change visually, other changes are less apparent, though important to consider, related to the nutritional quality for livestock grazing, ability of the individual plant to recover from defoliation (either from grazing or mowing), and the ability of the seed to continue to develop and later germinate after it is detached from the plant. While these changes are roughly predictable, variation from year to year, across regions, and even within pastures occurs due to
Table 1. Phenological stages of medusahead and barb goatgrass in California annual rangelands

\begin{tabular}{|c|c|c|}
\hline Stage & Description & Season* \\
\hline V1 & $\begin{array}{l}\text { Germination occurs at the onset of fall rains (roughly } \\
0.5-1 \text { inch of rain within } 5 \text { days) followed by growth of } \\
\text { the seed leaf. }\end{array}$ & fall \\
\hline V2 & $\begin{array}{l}\text { The early vegetative stage occurs with shortened day } \\
\text { length. Lower temperatures during the winter may inhibit } \\
\text { growth and last for months. }\end{array}$ & fall-winter \\
\hline V3 & $\begin{array}{l}\text { The late vegetative stage occurs as temperatures increase } \\
\text { in the late winter and early spring, characterized by } \\
\text { lengthening internodes and transition into the boot } \\
\text { stage. This stage indicates the start of the spring growing } \\
\text { season and quicker growth and development. }\end{array}$ & $\begin{array}{l}\text { late winter } \\
\text { to early to } \\
\text { mid-spring }\end{array}$ \\
\hline R4 & $\begin{array}{l}\text { Emergence of awns through the full emergence of the } \\
\text { inflorescence. }\end{array}$ & $\begin{array}{l}\text { mid to late } \\
\text { spring }\end{array}$ \\
\hline R5 & The florets open and anthers emerge (anthesis). & late spring \\
\hline R6 & Anthesis ends and kernels begin to form. & late spring \\
\hline R7 & Kernels elongate to reach the full length of the palea. & late spring \\
\hline R8 & $\begin{array}{l}\text { Seeds in the milk stage and kernels occupy the full length } \\
\text { of the palea. Seeds will continue to mature and become } \\
\text { viable if cut off. }\end{array}$ & $\begin{array}{r}\text { very late } \\
\text { spring }\end{array}$ \\
\hline R9 & Seeds in dough stage. & $\begin{array}{r}\text { very late } \\
\text { spring }\end{array}$ \\
\hline M10 & $\begin{array}{l}\text { All seeds are mature and hard. The plant is not yet dead, } \\
\text { though there is some red, brown, and green in the seed } \\
\text { heads. Glume veins are dark. }\end{array}$ & early summer \\
\hline D11 & $\begin{array}{l}\text { Seeds fully mature. Flowering stem is dead and dry. } \\
\text { The whole plant is a reddish-yellow (barb goatgrass) or } \\
\text { uniform sandy-yellow color (medusahead). This stage } \\
\text { includes seed head shatter and seed dispersal. }\end{array}$ & early summer \\
\hline L12 & $\begin{array}{l}\text { Plant material from the previous year is leached } \\
\text { of nutrients, leaving gray plant material (typically } \\
\text { medusahead has much more litter in this stage than } \\
\text { other annual grass species). }\end{array}$ & fall-winter \\
\hline
\end{tabular}

Source: Adapted from NRC 1982; George and Bell 2001.

Note: *Seasonal timing can vary widely with year and location. 
variation in weather, climate, landscape, presence of grazing, soil differences, and genetics. This means that predicting the timing for control can be somewhat imprecise, making the use of phenology observations imperative to optimize control treatments. University of California research conducted over multiple years describes how observations of plant growth stage can help to optimally time grazing and mowing treatments.

\section{Phenologic Stages of Barb Goatgrass and Medusahead}

The stages in table 1 provide a framework to describe how both of these species progress and change in their physical characteristics over the course of the growing season. The 12 stages are broken into vegetative stages V1 to V3, reproductive stages $\mathrm{R} 4$ to R9, a mature stage M10, a summer dry stage D11, and dead residual in the subsequent growing season at stage L12. Defining these stages helps to optimize the timing of grazing and mowing control treatments by defining the windows of susceptibility.

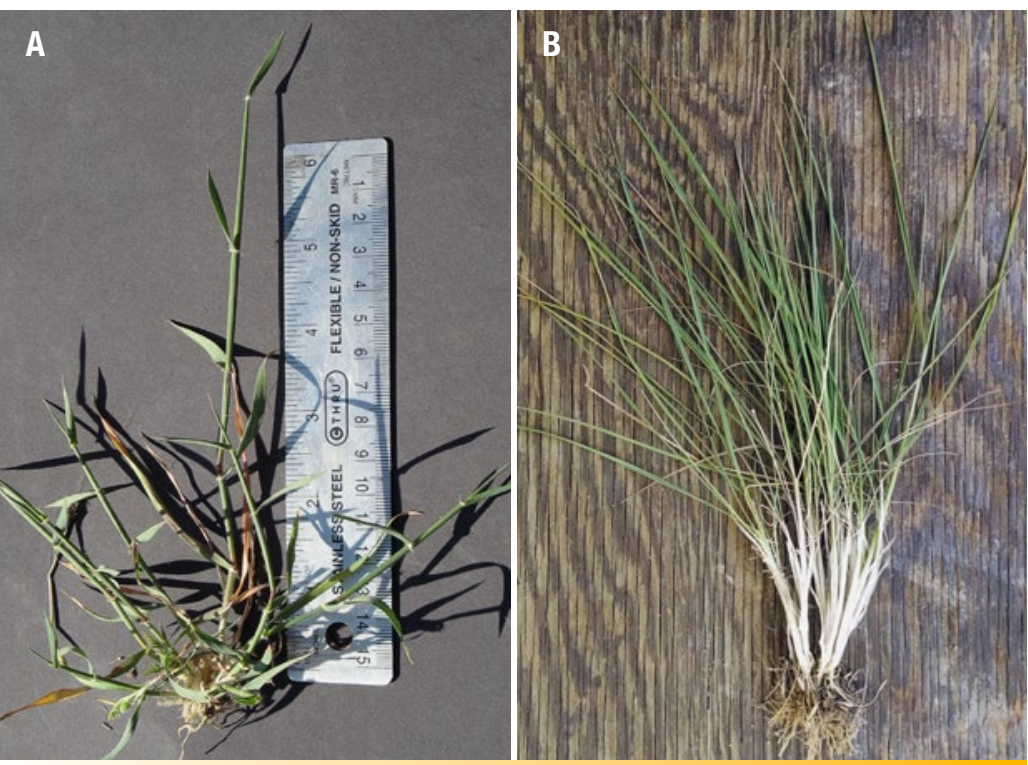

Figure 2. Barb goatgrass (A) and medusahead (B) in the boot stage (V3), when grazing treatments should be started. Photo: J. Davy.

\section{Applying Phenology to Grazing or Mowing Treatment Timing}

During the first two vegetative stages (V1 and V2) the plants are very small and inconspicuous. They are often unnoticed when viewed on a landscape level and provide very little forage for grazing. When plants are grazed during these stages they will readily recover with new flowering stems; thus, little to no control is achieved. In order to impact plants heavily enough to prevent further reproductive stages from progressing, targeted grazing (not mowing) of the infested areas should begin during the late vegetative stage 3 (V3) or boot stage (fig. 2). Plants are affected by grazing from stage V3 until the reproductive stage 4 (R4), when awns fully emerge, and neither grass species is palatable to grazing animals thereafter (in barb goatgrass and medusahead, the awn is quite long and injurious to grazing animals). Crude protein of the vegetative grasses drops significantly from approximately 10 to 11 percent at the V3 stage to 7 to 8 percent at the R4 stage (fig. 3 and

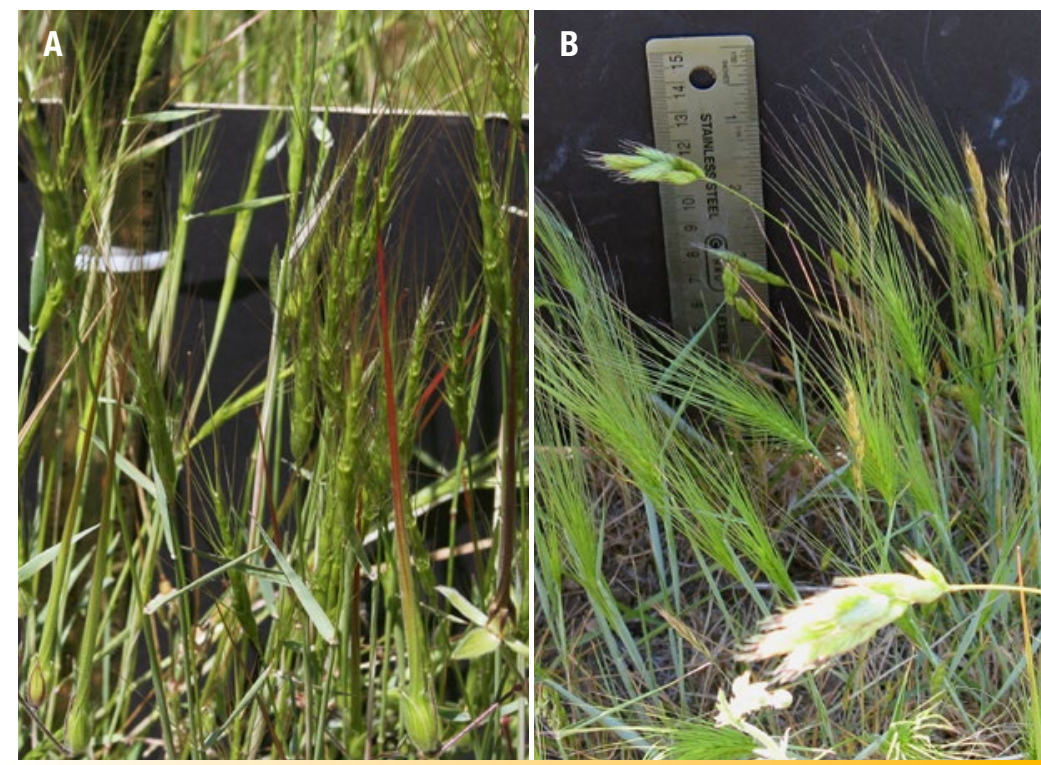

Figure 3. Barb goatgrass (A) and medusahead (B) in the early reproductive stage with awns fully emerged (R4). Photo: E. A. Laca (A); J. Davy (B). 
continues to drop to below 7 percent as the plant puts resources in to flower and seed development. The emergence of awns and loss of forage quality generally necessitate the grazing treatment period to end at this time. This creates a very small window for matching the impact of grazing with palatability, which generally only lasts two weeks.

After the onset of the R4 stage, the ability of these species to recover from defoliation is greatly reduced, which makes mowing a very successful treatment tool for both barb goatgrass and medusahead in the reproductive stages. Mowing prior to the R4 stage is largely a wasted effort as the plants will likely recover unless mowed again. The emergence of anthers can be a good visual indicator that the best timing for mowing has been reached. While not yet fully mature, once the seed has reached its full length (not obvious, but the kernel occupies the full length of the palea) in the R8 stage (fig. 4), the seed is able to continue to develop and become viable if spikes detach from the plant. This can be visually

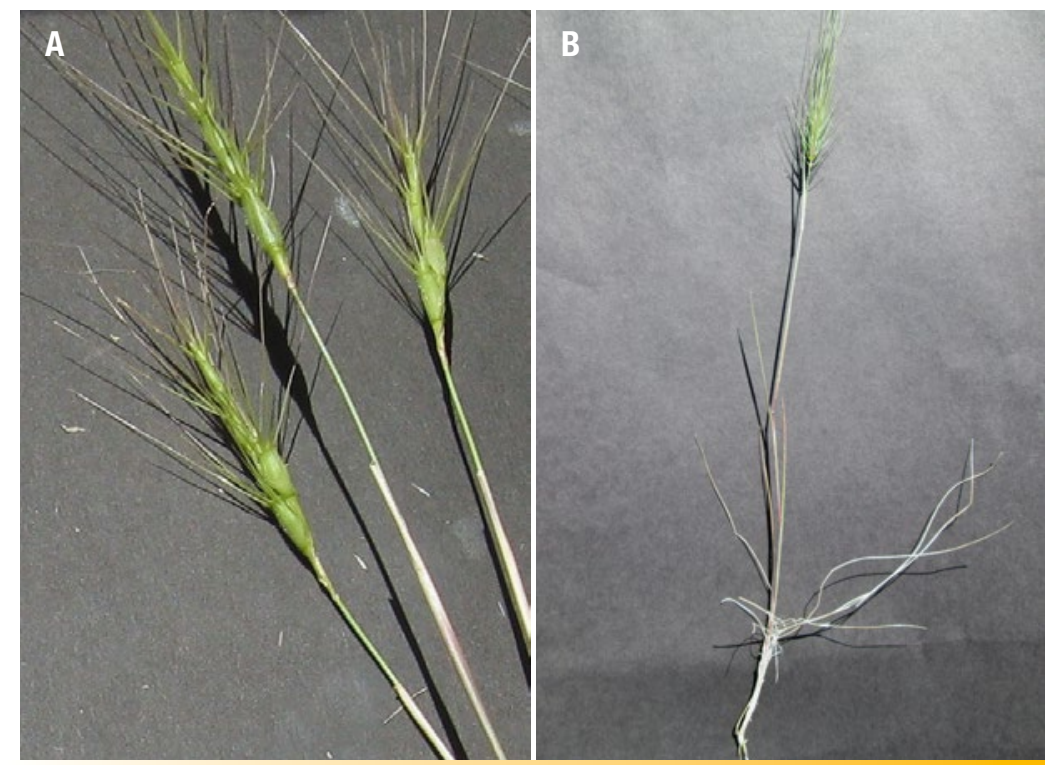

Figure 4. Barb goatgrass (A) and medusahead (B) with browning stems while the spike (seedhead) is still green, indicating the end of the period appropriate for mowing. Photo: J. Davy (A); P. Brownsey (B). approximated as the point that plant leaves and stem are turning brown, but the seeds and seed head are still green. The plant is fully mature once shades of red, brown, and green are apparent on the seed head (fig. 5). The window for treatment is much longer for mowing than grazing since palatability is not an issue.

\section{Timing of Phenologic States}

To better understand the timing of phenology of these two grasses in California, UC researchers measured the proportion of barb goatgrass and medusahead at various times through the growing season. Included were 18 locations in 11 counties from Shasta to Monterey at elevations from 80 to 990 feet above sea level during the growing season from 2006 to 2010 . Whereas medusahead was present at all sites, barb goatgrass was present in samples taken from Tehama County to Yolo County. The limited range of sample locations for barb goatgrass reflected the more restricted range of this species compared with medusahead (see Brownsey et al. 2016 for more details on the methods of this study).
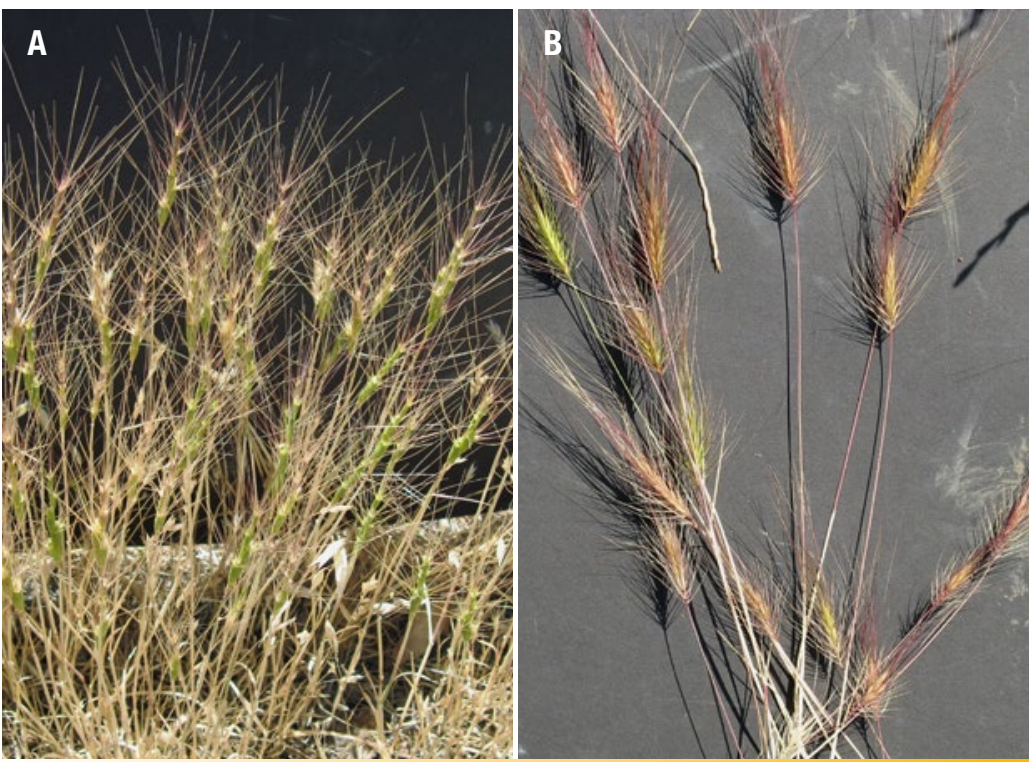

Figure 5. Barb goatgrass (A) and medusahead (B) after the period at which they are susceptible to mowing or grazing treatments. Photo: J. Davy. 
Medusahead was sampled over a larger geographic range than barb goatgrass, and we therefore expected and observed more variability in the timing of phenology of medusahead relative to barb goatgrass. Medusahead became susceptible to grazing treatments from early or mid-April to early or mid-May, depending on the site and year. The transition from grazing susceptibility to only mowing susceptibility reliably occurred in early May and was usually complete in mid-May. Medusahead tends to enter the stage of maturity that is too late for effective mowing treatment between the last week of May and the first week of June. Some cooler locations in the Central Coastal valleys can be about a week later. In addition, there seem to be some locations with warmer winter temperatures and less moisture overall where this transition to maturity occurs much earlier, such as early May. Select sites in Glenn, San Joaquin, and Shasta Counties were consistently 2 to 4 weeks earlier than other sites. This may be due to a number of factors, including locally warmer spring temperatures.

Barb goatgrass became susceptible to grazing treatments from mid-March to mid-April; however, grazing is not recommended at this time due to the existence of a dormant seed bank and lesscomplete control compared with mowing, making this approach challenging. In 2007, barb goatgrass began developing notably later; 2007 was the only year when barb goatgrass collections made in late March and early April were not yet susceptible to grazing. (This was a dry year with a dry spring and seemingly normal temperatures through the growing season. Given that only 2007 had this greater anomaly, it is difficult to draw conclusions regarding why this year was different.) During other years, the first collections made in early April were already susceptible to livestock grazing. The transition from susceptibility of grazing to only mowing reliably occurred in early May and was complete by mid-May. Generally, at all sites, barb goatgrass entered the stage of maturity that is too late for effective mowing treatment around June 1 , with a variance of about 5 days. One year (2007) seemed to have more variability, with several sites maturing earlier and others sites later than other years.

At the pasture scale, some individuals and patches of medusahead will mature more quickly than others due to variation in soils, slope, and aspect. In more-uniform pastures, most individual and patches of plants may be well synchronized, while in morevariable pastures there may be a greater range of stages at any given time in the spring. This can lead to patchy areas, with some grasses that are too early for treatment success and others that are too late for treatment success. Variable effects within pastures are amplified when they are not grazed. In these cases, managers will need to keep in mind that grazing should be considered a long-term approach that will not be fully successful every year (Davy et al. 2016).

\section{ImPLEMENTATION CONSIDERATIONS FOR Grazing ANd Mowing}

While the start of susceptibility varies substantially, ranging from late March to early May, the duration of susceptibility for both barb goatgrass and medusahead tends to vary across its range and from year to year, but in somewhat predictable patterns. The period of susceptibility of medusahead to targeted grazing is 2 to 3 weeks, while susceptibility to mowing of both species is about 5 weeks. The length of these periods varies by year, location, precipitation, and soils (table 2). Cooler spring seasons tend to lengthen the period of susceptibility relative to drier, warmer sites and years.

Livestock stocked at moderate or light stocking rates will avoid medusahead and goatgrass particularly as plants transition from

Table 2. Range and length of time when the optimal grazing or mowing treatment window for barb goatgrass and medusahead will likely occur in California annual grasslands

\begin{tabular}{|c|c|c|c|}
\hline \multirow[t]{2}{*}{ Treatment } & \multirow[t]{2}{*}{ Plant stage } & \multicolumn{2}{|c|}{ Observed treatment timing range* } \\
\hline & & Barb goatgrass & Medusahead \\
\hline grazing & V3 to $\mathrm{R} 4$ & $\begin{array}{l}2 \text { to } 3 \text { weeks }{ }^{\dagger} \text { in } \\
\text { March to May }\end{array}$ & $\begin{array}{c}2 \text { to } 3 \text { weeks in early } \\
\text { April to May }\end{array}$ \\
\hline mowing & $\mathrm{R} 5$ to $\mathrm{R} 8$ & $\begin{array}{l}5 \text { weeks in } \\
\text { May to early June }\end{array}$ & $\begin{array}{l}5 \text { weeks in late } \\
\text { April to early June }\end{array}$ \\
\hline
\end{tabular}

Notes:

*Timing in warmer and drier locations will likely be earlier than in the cooler and moister locations.

†Targeted grazing for barb goatgrass would theoretically occur during this period, but we cannot recommend this as an effective treatment since sufficient research is currently not available showing this to be effective. 
V3 to R4. To overcome this aversion, heavy stocking rates that far exceed rates considered normal for annual rangelands are required to encourage enough consumption to impact seed production. For grazing to be successful, plants must be impacted enough to prevent the onset of seed set. This is possible because these two species tend to mature so late in the season that soil moisture is not present in adequate amounts for plant recovery (DiTomaso et al. 2008), although this is not the case every year. The rate is determined by the forage biomass present, but it often exceeds 1 to 2 animal units (mature cow) per acre during the critical V3 and early R4 stages. This high rate is necessary because of the short window and amount of forage that needs to be removed. The objective is to consume

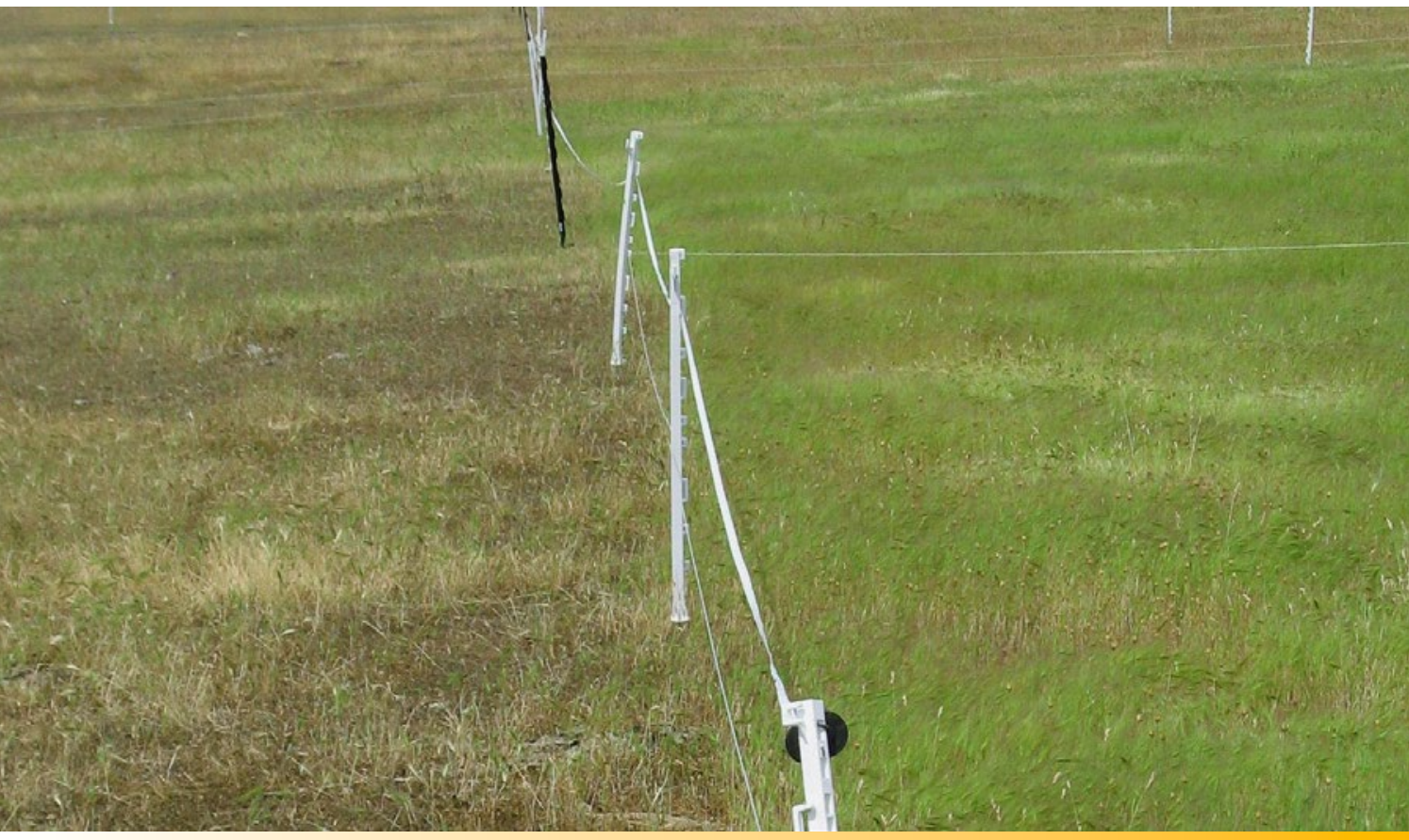

Figure 6. Timed grazing of medusahead (left side of photo), showing appropriate targeted grazing leaving residual forage of about 500 pounds per acre; ungrazed medusahead (right). Photo: J. Davy. forage biomass to, or even slightly below, 500 pounds per acre (fig. 6). This makes treatment site-specific within most ranches because of the difficulty of fencing, watering, and providing enough cattle to impact an area, as well as the increased management time.

The short period of susceptibility for successfully implementing a grazing treatment can be overcome with mowing treatments. When implemented correctly, mowing is more likely to be a successful treatment than grazing because the timing will almost, but not always, prevent subsequent seed production. However, mowing faces other challenges, including the inability to cover steep terrain, rocks that damage the mower, and fire potential, which are very common scenarios on California rangelands.

It is important to ensure that these treatments are applied as effectively as possible to get the most benefit out of them. By understanding the phenology of barb goatgrass and medusahead, these treatments can be better planned so that the timing and intensity of treatment corresponds to when they will most effectively reduce the abundance of these noxious annual grasses in the future.

\section{Other Control Methods}

Grazing and mowing are two of many successfully tested weed control methods that can be used in combination with (or instead of) other methods for medusahead and barb goatgrass control. Using multiple methods is highly suggested for barb goatgrass areas. Ultimately, treatment decisions are site and management specific. Specifics on the effectiveness and implementation of the various other treatment options, such as burning and herbicide application, are available from sources such as Davy et al. 2008, DiTomaso and Kyser 2013, and Kyser et al. 2014. In addition, articles by Aigner and Woerly (2013) and James et al. (2015) have also assessed the effectiveness of different treatment tools on barb goatgrass and medusahead, respectively. 
Figure 7. Anatomy of barb goatgrass (A) and medusahead (C) spikes, with dissected florets, and a drawing of a grass spikelet (B) containing two florets for comparison. The ruler tick marks are in millimeters. Photos: E. Laca (A, C); drawing: P. Brownsey (B).
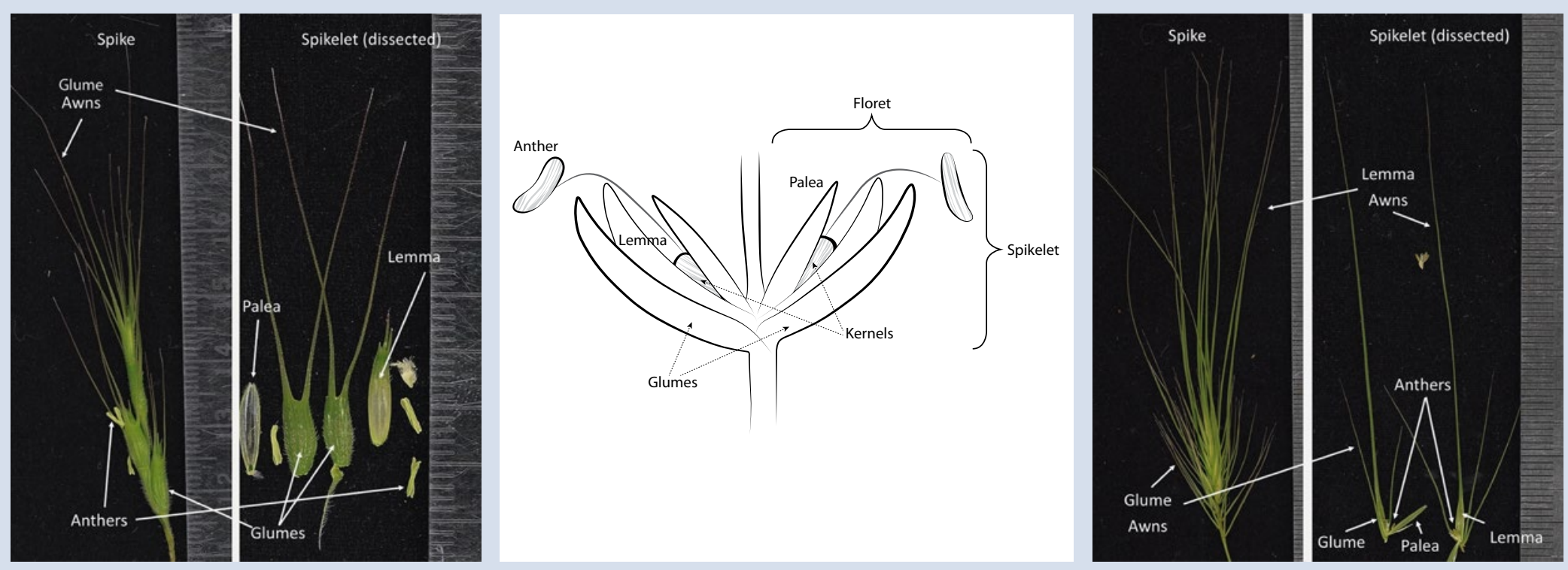

\section{GLOSSARY}

awn. A bristle extending from the tip or back of the glume, lemma, or kernel.

boot stage. The transitional growth stage of a grass from vegetative to reproductive, during which the inflorescence (seed head) is developing within the stem.

anther. Pollen-bearing portion of the stamen that is extended out of the floret on a filament in barb goatgrass and medusahead during pollination.

anthesis. The period during which anthers are exposed to disburse pollen.

bract. A very small leaf that often encloses a plant part; may be papery or very tough.

floret. A single grass flower, including a lemma and palea and the parts within it.

glume. A pair of bracts at the base of the spikelet.

inflorescence. The reproductive parts of a plant; the spike in barb goatgrass and medusahead.

kernel. The developing seed, from ovary to full maturity.

lemma. A single bract at the base of the floret.

palea. Inner bract of a floret enclosing the kernel.

spike. An unbranched collection of spikelets along a central stem, such as the inflorescence of barb goatgrass and medusahead.

spikelet. The basic unit of the inflorescence of a grass, consisting of two glumes and one or more florets. 


\section{References}

Aigner, P. A., and R. J. Woerly. 2011. Herbicides and mowing to control barb goatgrass (Aegilops triuncialis) and restore native plants in serpentine grasslands. Invasive Plant Science and Management 4(4): 448-457.

Baldwin, B. G., D. H. Goldman, D. J. Keil, R. Patterson, et al., eds. 2012. The Jepson manual: Vascular plants of California. 2nd ed. Berkeley: University of California Press.

Brownsey, P., J. J. James, S. J. Barry. T. A. Becchetti, et al. 2016. Using phenology to optimize timing of mowing and grazing treatments for medusahead (Taeniatherum caput-medusae). Rangeland Ecology and Management. doi: http://dx.doi. org/10.1016/j.rama.2016.08.011

Calflora. 2015.The Calflora Database website, http://www. calflora.org.

Davy, J. S., J. M. DiTomaso, and E. A. Laca. 2008. Barb goatgrass. Oakland: University of California Division of Agriculture and Natural Resources Publication 8315. UC ANR catalog website, http://anrcatalog.ucanr.edu/Details.aspx?item $\mathrm{No}=8315$.

Davy J. S., L. M. Roche, D. E. Nay, and K. W. Tate. 2014. Introducing cattle grazing to a noxious weed-dominated rangeland shifts plant communities. California Agriculture 69(4): 230-236.

DiTomaso, J. M., G. B. Kyser, M. R. George, et al. 2008. Control of medusahead (Taeniatherum caput-medusae) using timely sheep grazing. Invasive Plant Science and Management 1(3): 241-247.

DiTomaso, J. M., G. B. Kyser, S. R. Oneto, et al. 2013. Weed control in natural areas in the Western United States. University of California Weed Research and Information Center website, http://wric.ucdavis.edu/information/natural areas/natural_areas_common_A-B.htm.
Duncan, C. A., J. J. Jachetta, M. L. Brown, et al. 2004. Assessing the economic, environmental, and societal losses from invasive plants on rangeland and wildlands. Weed Technology 18:1411-1416.

George, M. R., and M. E. Bell. 2001. Using stage of maturity to predict the quality of annual range forage. Oakland: University of California Division of Agriculture and Natural Resources Publication 8019. UC ANR Catalog website, http://anrcatalog. ucanr.edu/Details.aspx?itemNo $=8019$.

Hitchcock, A. S., and A. Chase. 1971. Manual of the grasses of the United States. Volume 2. 2nd ed. New York: Dover.

James, J. J., E. S. Gornish, J. M. DiTomaso, et al. 2015. Managing medusahead (Taeniatherum caput-medusae) on rangeland: A meta-analysis of control effects and assessment of stakeholder needs. Rangeland Ecology and Management 68(2): 215-223.

Kyser, G. B., J. M. DiTomaso, K. W. Davies, et al. 2014. Medusahead management guide for the western states. UC Weed Research and Information Center website, http://wric. ucdavis.edu/publications/MedusaheadManagementGuide_ pub_2014.pdf.

Meimberg, H., J. I. Hammond, C. M. Jorgensen, et al. 2006. Molecular evidence for an extreme genetic bottleneck during introduction of an invading grass to California. Biological Invasions 8:1355-1366.

NRC (National Research Council). 1982. United States-Canadian tables of feed composition: Nutritional data for United States and Canadian feeds. Third Revision. Washington, DC: The National Academies Press. 


\section{For MORE Information}

To order or obtain ANR publications and other products, visit the ANR Communication Services online catalog at http://anrcatalog.ucanr.edu or phone 1-800-994-8849. You can also place orders by mail or FAX, or request a printed catalog of our products from

University of California

Agriculture and Natural Resources

Communication Services

1301 S. 46th Street

Building 478 - MC 3580

Richmond, CA 94804-4600

Telephone 1-800-994-8849

510-665-2195

FAX 510-665-3427

E-mail: anrcatalog@ucanr.edu

(02016 The Regents of the University of California. This work is licensed under the Creative Commons Attribution-NonCommercial-NoDerivatives 4.0 International License. To view a copy of this license, visit http://creativecommons.org/licenses/by-nc-nd/4.0/ or send a letter to Creative Commons, PO Box 1866, Mountain View, CA 94042, USA.

\section{Publication 8567}

ISBN-13: 978-1-60107-971-8

The University of California, Division of Agriculture and Natural Resources (UC ANR) prohibits discrimination against or harassment of any person in any of its programs or activities on the basis of race, color, national origin, religion, sex, gender, gender expression, gender identity, pregnancy (which includes pregnancy, childbirth, and medical conditions related to pregnancy or childbirth), physical or mental disability, medical condition (cancerrelated or genetic characteristics), genetic information (including family medical history), ancestry, marital status, age, sexual orientation, citizenship, status as a protected veteran or service in the uniformed services (as defined by the Uniformed Services Employment and Reemployment Rights Act of 1994 [USERRA]), as well as state military and naval service.

UC ANR policy prohibits retaliation against any employee or person in any of its programs or activities for bringing a complaint of discrimination or harassment. UC ANR policy also prohibits retaliation against a person who assists someone with a complaint of discrimination or harassment, or participates in any manner in an investigation or resolution of a complaint of discrimination or harassment. Retaliation includes threats, intimidation, reprisals, and/or adverse actions related to any of its programs or activities.

UC ANR is an Equal Opportunity/Affirmative Action Employer. All qualified applicants will receive consideration for employment and/or participation in any of its programs or activities without regard to race, color, religion, sex, national origin, disability, age or protected veteran status.
University policy is intended to be consistent with the provisions of applicable State and Federal laws.

Inquiries regarding the University's equal employment opportunity policies may be directed to: John Sims, Affirmative Action Contact and Title IX Officer, University of California, Agriculture and Natural Resources, 2801 Second Street, Davis, CA 95618, (530) 750-1397. Email: jsims@ucanr.edu. Website: http://ucanr.edu/sites/anrstaff/Diversity/Affirmative_ Action.

An electronic copy of this publication can be found at the ANR Communication Services catalog website, http://anrcatalog.ucanr.edu.

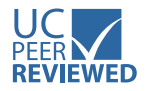

This publication has been anonymously peer reviewed for technical accuracy by University of California scientists and other qualified professionals. This review process was managed by ANR Associate Editor for Agronomy and Range Sciences Rachael Freeman Long.

web-10/16-SB/KF 